\title{
REPORTABLE ARRANGEMENTS: TAX PARTNER PERCEPTIONS OF SOME PROBLEMATIC TERMINOLOGY
}

\author{
Lee-Ann Steenkamp* \\ University of the Western Cape \\ Lee-ann@outlook.com
}

Received: October 2013

\author{
Peter Cramer+ \\ University of Cape Town
}

Accepted: November 2013

\begin{abstract}
The South African Revenue Service (SARS) implemented a more aggressive reporting system in 2008 by introducing new reportable arrangements ('RA') provisions in the Income Tax Act. In March 2010, SARS issued a revised Draft Guide to Reportable Arrangements for public comment. More than three years after its release, there is still no finalised, updated guide available to address the 'new' RA provisions. Determining when arrangements should be reported to SARS therefore remains both problematic and onerous. It is the purpose of this article to examine some of the problematic terminology in an attempt to afford South African taxpayers greater clarity in the identification and disclosure of RAs. The research findings are tested through a survey conducted among tax partners and directors at a sample of 40 leading audit and legal firms in South Africa. The majority of respondents agreed with the conclusions drawn from the literature study.
\end{abstract}

Keywords

Arrangement; Participant; Penalty; Promoter; Reportable Arrangement; SARS; South Africa; Tax Administration Act; Tax Benefit; Tax partner

*Ms L-A Steenkamp is a lecturer in the Department of Accounting, University of Western Cape, South Africa.

\#Mr P Cramer is a lecturer in the College of Accounting, University of Cape Town, South Africa. 


\section{BACKGROUND AND FORMULATION OF THE STUDY}

\subsection{Background}

The Organisation for Economic Cooperation and Development (OECD) has initiated a global forum on the transparency and exchange of information for tax purposes. The forum correctly observes that although globalisation generates opportunities to increase global wealth, it also results in increased risks (OECD, 2011). The South African Revenue Service (SARS) concurs with the $0 \varepsilon C D$ and acknowledges that the inevitable delays between the conclusion of transactions, the submission of the related annual returns, and the returns' assessment and audit mean that years may pass before the transactions are detected, analysed and challenged (SARS, 2008).

According to SARS (2008), one measure to improve response times, which is increasingly being adopted worldwide, involves the advance reporting of transactions meeting criteria that indicate that they may give rise to concern. These advance reporting rules (in the form of the first reportable arrangements provisions) were introduced to the Income Tax Act No. 58 of 1962, as amended, (the Act) by section 76A and came into effect on 1 March 2005. Section 76A was repealed on 1 April 2008 and replaced with a new Part IIB, which contains sections 80M to 80T. These reportable arrangements provisions (hereafter collectively referred to as the 'RA provisions') apply to any arrangement entered into with effect from 1 April 2008.

The Tax Administration Act No. 28 of 2011 (the 'TAA') came into force on 1 October 2012. As the TAA has as its objective to incorporate administrative provisions into one piece of legislation and to harmonise provisions as far as possible (SARS, 2013:4), the RA provisions were removed from the Act and were included as sections 34 to 39 in Part B of Chapter 4 'Returns and Records' of the TAA. The penalty provision of section $80 \mathrm{~S}$ of the Act is now included as section 212 in Part B 'Fixed Amount Penalties' of Chapter 15 'Administrative Non-compliance Penalties' of the TAA. Except for the penalty provision and the definition of 'arrangement', the remainder of the RA provisions were transferred verbatim from the Act to the TAA. (Refer to the APPENDIX 1 for the current wording of the RA provisions as contained in the TAA.)

On 31 March 2010, SARS issued a revised Draft Guide to Reportable Arrangements (the 'Draft Guide') for public comment (SARS, 2010). The Draft Guide, which seeks to address the new RA provisions, has not been issued in its final format and no response document to public commentary has been released by SARS yet. In e-mail and telephone correspondence with SARS's Legal \& Policy Division, SARS could not confirm if and when the new guide would be released, nor if and when they would publish any response document. To further exacerbate matters, the 2010 guide no longer appears to be available on SARS's recently revamped website. The only guide currently displayed in the list of guides is the previous 2005 guide. (To obtain an electronic copy of the 2010 Draft Guide, please e-mail the corresponding author.)

Consequently, more than three years after the release of the Draft Guide, there is still no finalised, updated guide available to address the 'new' RA provisions. Accordingly, determining when arrangements should be reported to SARS remains both problematic and onerous. It is therefore submitted that South African taxpayers still require clarification on certain problematic terminology contained in the RA provisions. 


\subsection{Research objective}

Although the new Draft Guide is certainly a step in the right direction for SARS, it is submitted that the discrepancies and ambiguities contained in the Act and the guide itself have not been adequately addressed. The interpretation of the RA provisions could thus be subjective and difficult to apply in practice. This is evidenced by the number of sets of comments and recommendations that the South African Institute of Chartered Accountants (SAICA) has made to SARS (SAICA, 2004; 2007a; 2007b; 2008 \& 2010a).

It is therefore the purpose of this article to examine some of the problematic terminology contained in the RA provisions in an attempt to afford South African taxpayers greater clarity in the identification and disclosure of reportable arrangements. The Draft Guide will be used as a starting-point and will be critically examined to identify any errors or anomalies.

\subsection{Research method}

Both a literature study and an empirical study were performed. The article is structured as follows:

- The article commences with an examination of selected terminology contained in the RA provisions and the Draft Guide. This consists of a literature review of South African statutory law, court decisions and published articles and textbooks.

- The article subsequently tests some of the research findings in a survey conducted among the tax partners at a sample of leading audit and legal firms in South Africa.

- Lastly, the article also makes a number of recommendations in an effort to elucidate the problematic terminology addressed earlier.

Due to the fact that, at the time the survey was conducted (in 2011) the provisions of the TAA were not yet enacted, only sections $80 \mathrm{M}$ to $80 \mathrm{~T}$ of the Act are referred to throughout this article. Accordingly, the survey that was conducted among tax partners at a sample of audit and legal firms also referred to sections $80 \mathrm{M}$ to $80 \mathrm{~T}$ and not to the TAA provisions. Note that this has no impact on the survey results, as the RA provisions were largely just transferred from one piece of fiscal legislation to another.

\section{REPORTABLE ARRANGEMENTS TERMINOLOGY}

\subsection{Introduction}

A reportable arrangement is defined in section $80 \mathrm{~T}$ of the Act as any arrangement contemplated in section $80 \mathrm{M}$. Such an arrangement must be reported to the Commissioner of SARS within 60 days in terms of the disclosure obligation of section 800 . Failure to disclose such arrangements may result in a Rl million penalty in terms of section $80 \mathrm{~S}$. The TAA contains a revised penalty clause in section 212 (which can be found in Appendix 1).

Sections $80 \mathrm{M}(1)$ and (2) identify arrangements that are considered to be reportable to the Commissioner, and section $80 \mathrm{~N}(1)$ contains a list of arrangements that are specifically excluded from the reportable arrangements provisions. Reportable arrangements can be classified into two categories. One category is contained in section $80 \mathrm{M}(2)$ and refers to hybrid equity 
instruments, hybrid debt instruments and any arrangement identified by the Minister by notice in the Government Gazette as an arrangement that is likely to result in any undue tax benefit.

The other category is contained in section $80 \mathrm{M}(\mathrm{l})$ and relates to arrangements that result in a tax benefit (as stated in the introductory requirement of section $80 \mathrm{M}(1)$ ) and meet the requirements of one of five scenarios found in sections $80 \mathrm{M}(1)(a)$ to $(e)$.

\subsection{Rules of interpretation for South African fiscal legislation}

Clegg and Stretch (2010:par2.1) remark that income tax is essentially the creature of statute, and the principles of construction that apply to statutes generally apply equally to the interpretation of taxation statutes. They further observe that the interpretation of statutes is often a difficult task, and that the rules of construction, which vacillate from a literal application to one based on the aims and context of the legislation, are not applied consistently. It is, however, beyond the scope of this article to discuss the rules of interpretation or the intricacies and difficulties in interpreting fiscal legislation.

Briefly, there are two broad approaches to the interpretation of statutes in common law tradition, namely the traditional and the modern approach. Du Plessis (2002:93-98) explains that each of these approaches consists of two general theories to interpretation. In the case of the traditional approach, there are the literalist and intentionalist theories, and in the case of the modern approach the purposivist and contextualist theories.

Irrespective of which approach or theory is applied, De Ville (2000:par8.3) states that the role of the courts is to ensure that statutes comply with the requirements of the Constitution. Accordingly, the next paragraph will examine the interpretation of fiscal legislation in light of the values of the Constitution.

\subsection{Applying Constitutional principles to the interpretation of fiscal legislation}

The principles for the interpretation of statutes are to be derived from the Constitution. The Constitution of the Republic of South Africa Act No. 108 of 1996, as amended (the Constitution), was promulgated in 1993 and enacted in 1996. Section 1 of the Constitution indicates that the Constitution is superior to all other legislation, as the Bill of Rights applies to all law, and binds the legislature, the executive, the judiciary and all organs of state. Section 3 determines that when applying a provision of the Bill of Rights to a natural or juristic person, a court, in order to give effect to a right in the Bill:

(a) ...must apply, or if necessary develop, the common law to the extent that legislation does not give effect to that right; and

(b) may develop rules of the common law to limit the right, provided that the limitation is in accordance with section 36(1).

As regards constitutional and statutory interpretation, sections 39(1) and (2) state the following:

(1) When interpreting the Bill of Rights, a court, tribunal or forum -

(a) must promote the values that underlie an open and democratic society based on human dignity, equality and freedom;

(b) must consider international law; and 
(c) may consider foreign law.

(2) When interpreting any legislation, and when developing the common law or customary law, every court, tribunal or forum must promote the spirit, purport and objects of the Bill of Rights.

Section 39(1) of the Constitution gives specific instructions on how to interpret the Bill of Rights. Section 39(2) deals with the interpretation of any other legislation. These sections command a similar interpretative approach to both the Constitution and statutes. Statutory interpretation is therefore to be seen not as a search for the intention of the legislature but an enforcement of constitutional values (De Ville, 2000:par 8.3).

Thus, the primary aim of statutory interpretation should be to ensure that the statute is in accordance with the aims and values of the Constitution. Both the interpretation of the Bill of Rights specifically and other sections of the Constitution in general (including fiscal legislation by implication) must promote the values that underlie an open and democratic society based on human dignity, equality and freedom.

Goldswain (2008:115) indicates that sections 39(1) and 39(2) oblige the judiciary, when interpreting statutes to, inter alia, promote the protection of the liberty of persons, their property and the enforcement of the principles of human dignity, equality and fairness. He notes that these qualities are central to the purposive theory to the interpretation of statutes.

De Ville adopts a similar view (2000:par 8.4.1). He indicates that the Constitution requires statutes to be interpreted by following a broad contextual approach. The context in which the statute is interpreted should include the constitutional values, the statute's background and purpose (viewed in the light of the aims of the Constitution), other statutes as well as the social, political and economic context and (where relevant) comparative and foreign law.

An analysis of the decided cases indicates that over the years the judiciary has gradually shifted from the so-called 'strict' interpretation of fiscal legislation to a purposive approach (Goldswain, 2008:119). The automatic application of the strict or literal approach to the interpretation of fiscal legislation is no longer, in theory, a viable option for the judiciary, especially in cases where inequitable and unjust consequences arise as a result of applying such an approach. However, in practice, the strict rule of interpretation will be used in circumstances where such interpretation is not in conflict with the overall as well as the specific intention or purpose of the legislature.

Accordingly, this literature study considers the meaning that the courts have ascribed to the words contained in the RA provisions, as well as their ordinary, grammatical meaning (which is found in dictionaries). All references to dictionary definitions in the literature review are those of the Oxford Dictionaries Online (2010) and the Chambers Online Dictionary (2010).

Before the RA provisions can apply, an arrangement must first be entered into. The following paragraph will analyse the term 'arrangement'.

\subsection{Arrangement}

An arrangement, according to section $80 \mathrm{~T}$, means any transaction, operation or scheme. However, 'transaction', 'operation' and 'scheme' are not defined in the Act. One therefore has to look at the meaning the courts have ascribed to them as well as their ordinary, grammatical meaning. Also, the precise identification of the transaction, operation or scheme is of vital 
importance to the taxpayer to avoid any misunderstanding in determining whether or not the 'arrangement' is reportable.

The ordinary meaning of the words 'arrangement', 'transaction', 'operation' and 'scheme' can be found in any reputable dictionary and are as follows:

\begin{tabular}{ll}
\hline $\begin{array}{l}\text { Arrangement (noun) } \\
\text { Transaction (noun) }\end{array}$ & $\begin{array}{l}\text { A plan for a future event; an agreement. } \\
\text { Operation of buying or selling; the action of conducting business. }\end{array}$ \\
Scheme (noun) & $\begin{array}{l}\text { The action or process of operating or being active; an action or } \\
\text { series of actions which have a particular effect. }\end{array}$ \\
& $\begin{array}{l}\text { A systematic plan or arrangement for achieving a particular } \\
\text { object or effect; a secret plan intended to cause harm or } \\
\text { damage. }\end{array}$
\end{tabular}

An arrangement therefore encompasses a wide range of steps or actions in order for a future event to take place. De Koker (2010:par 19.4) states that an arrangement requires a conscious involvement of two or more participants who arrive at an understanding. It presupposes a meeting of the minds or an expectation by each party that the other will act in a particular way. Support for this can be found in Newton v. COT (1958), where Lord Denning expressed the view (at paragraph 760) that:

$[T]$ he word 'arrangement' is apt to describe something less than a binding contract or agreement, something in the nature of an understanding between two or more persons ...

Thus, an arrangement includes different kinds of concerted action by which persons may arrange their affairs to produce a particular effect.

The terms 'transaction, operation or scheme' were considered in Meyerowitz v. CIR (1963), which was decided under section 90 of the Income Tax Act No. 31 of 1941. The Appellate Division of the Supreme Court agreed with the following finding of Watermeyer $J$ in the court a quo (at paragraph 300):

The word 'scheme' is a wide term and I think that there can be little doubt that it is sufficiently wide to cover a series of transactions.

In the Meyerowitz case, the appellant submitted that the transactions he entered into were not a preconceived plan and that the continuity of operations and connection between the different steps were lacking in such a degree as not to constitute a scheme. However, the Appellate Division held that from beginning to end, the transactions constituted a scheme even though they were not all contemplated at the outset. The important test that the Appellate Division applied is as follows: if the different steps, upon examination in retrospect, appear to be so connected with one another that they could ultimately lead to the avoidance of taxation, the transactions are a scheme. As stated in the Meyerowitz case (at paragraph 299):

Merely because the final step to secure this objective is left unresolved at the outset, and decided on later, does not seem to me to rob the scheme of the necessary unity to justify its being called an 'arrangement'.

Clegg and Stretch (2010:par 26.3.2) maintain that the fact that the intention to avoid the payment of tax appears only from later steps is of no consequence. This argument is supported by CIR v. Louw (1983), where the court found that if there was sufficient unity between the 
ultimate step and what has gone before, having regard to the ultimate objective, then together they might be regarded as being part and parcel of a single scheme. Moreover, in the Meyerowitz case, an act that did not form part of the scheme when it was entered into could become part and parcel of the scheme if it was later pressed into the service of the scheme.

Also noteworthy is the fact that in Ovenstone v. CIR (1980) it was held (at paragraph 68) that, in respect of an arrangement, 'entered into' does not mean 'formulated':

\begin{abstract}
Because of its context it has, I think, a connotation of implementation that is similar to 'carried out'. Probably both expressions were used because it was considered that 'carried out' is more appropriate to connote the implementation of a 'scheme', while 'entered into' is more apposite to connote the implementation (i.e. the taxpayer's actually engaging in ) of a 'transaction' or 'operation'.
\end{abstract}

Therefore, 'carried out' is considered by the courts to be similar to 'formulated' and is to be used in the context of a 'scheme'. The phrase 'entered into' is considered more appropriate in the context of 'transactions' and 'operations', as the taxpayer engages in the implementation thereof.

SARS introduced the RA provisions after the new General Anti-avoidance Rule (GAAR) provisions of sections $80 \mathrm{~A}$ to $80 \mathrm{~L}$ of the Act were brought into effect on 2 November 2006. SARS wanted to link the RA legislation to the factors that are indicative of a lack of commercial substance for GAAR purposes (SARS, 2006). It might therefore be useful to refer to the GAAR provisions if they contain definitions similar to those of the RA provisions. One of these similarities is found in the definition of an 'arrangement'.

Section $80 \mathrm{~L}$ of the GAAR provisions defines an arrangement so as to mean:

any transaction, operation, scheme, agreement or understanding (whether enforceable or not), including all steps therein or parts thereof, and includes any of the foregoing involving the alienation of property.

Clearly, the section 80L GAAR definition has a wider scope than the section 80T RA definition. The section $80 \mathrm{~L}$ definition also refers to an 'understanding' (whether enforceable or not). The ordinary meaning of the word 'understanding' is as follows:

Understanding (noun) An informal or unspoken agreement or arrangement; a condition agreed upon.

De Koker (2010:par 19.4) suggests that regardless of whether an agreement is reduced to writing and explicitly records all the terms and conditions, or whether it merely constitutes a verbal broad understanding of proposed future conduct which will more than likely take place, it will constitute an arrangement. In BNZ Investments Ltd v. CIR (2000) the word 'understanding' suggested (at paragraph 732):

something like a dealing between two or more persons, so that a taxpayer who deliberately refuses to see the obvious, but proceeds with a transaction in which the obvious occurs downstream, readily enough could be held to be part of at least an understanding to that effect. A taxpayer who actually knows all the details, and proceeds nevertheless, is of course, at equal or greater risk. (emphasis added)

It is suggested (De Koker, 2010:par 19.4) that the descending order of the terms transaction, operation, scheme, agreement or understanding may suggest descending degrees of enforceability. While an agreement is ordinarily (but not necessarily) legally enforceable, an understanding may not be. 
The section $80 \mathrm{~L}$ definition of 'arrangement' furthermore includes 'all steps therein or parts thereof'. The section $80 \mathrm{~T}$ definition contains no such phrase. The terms 'steps' and 'parts' are not defined. De Koker (2010:par 19.4) suggests that each connotes a distinct transactional element of the whole. Thus, the 'steps' or 'parts' constitute arrangements in themselves, and the Commissioner has the power to apply the GAAR to each such step or part.

Due to SARS's stated objective of minimising tax avoidance and countering tax abuse more quickly, it is submitted that SARS should amend the section $80 \mathrm{~T}$ definition of an 'arrangement' to align it with the section $80 \mathrm{~L}$ GAAR definition. This should assist in widening the potential scope of the RA provisions, thereby combating tax avoidance more effectively.

At first glance it is gratifying to observe that the Taxation Laws Amendment Act No. 24 of 2011 revised the section $80 \mathrm{~T}$ definition for 'arrangement' (in the RA provisions), thereby echoing the submission made above. The amended section, which came into operation on 1 April 2012, defines an 'arrangement' so as to mean any transaction, operation, scheme, agreement or understanding (whether enforceable or not), including all steps therein or parts thereof, and includes any of the foregoing involving the alienation of property. This amendment widened the scope of an 'arrangement' considerably.

Nevertheless, it should be pointed out that the TAA now contains a different definition of an 'arrangement'. Section 34 of the TAA (which is part of the RA provisions) defines an 'arrangement' so as to mean a transaction, operation, scheme, agreement or understanding (whether enforceable or not). Although it is more broadly defined than the former section $80 T$ (prior to the 2011 amendment), it will not have the same reach as the (now obsolete) revised section 80 T definition.

Much of the uncertainty surrounding the interpretation and application of the RA provisions is due to the very broad definition of a tax benefit. The next paragraph will address this problematic term.

\subsection{Tax benefit}

A tax benefit is defined in section $80 \mathrm{~T}$ so as to include any avoidance, postponement or reduction of any liability for tax. The tax referred to here is also defined in section $80 T$. This definition includes any tax, levy, duty or other liability imposed by this Act or any other Act administered by the Commissioner.

The definition of a tax benefit clearly encompasses a wide range of taxes and benefits. It is precisely this broad definition that results in many of the anomalies surrounding RAs. As previously stated, the GAAR provisions might prove helpful in interpreting the RA provisions. Section $80 \mathrm{~L}$ used to contain a definition for 'tax benefit', the wording of which is exactly the same as that of section $80 \mathrm{~T}$, namely

any avoidance, postponement or reduction of any liability for tax.

The Taxation Laws Amendment Act No. 7 of 2010 moved this definition out of section 80L and included it under section 1 . The wording was left unchanged.

Section $80 T$ defines 'tax' as including:

Any tax, levy, duty or other liability imposed by this Act or any other Act administered by the Commissioner. 
Section $80 \mathrm{~L}$ also defines 'tax' so as to include:

any tax, levy or duty imposed by this Act or any other Act administered by the Commissioner.

The wording is materially the same, except in section $80 \mathrm{~T}$, where 'or other liability' is also included. SARS has not provided any reason for this difference. The section $80 \mathrm{~T}$ reference to 'other liability' possibly widens the application of the RA provisions. In the Draft Guide, SARS (2010:10-11) considers the following to form part of the definition of a 'tax benefit':

- any deductions that are, or will be, or which are anticipated to be claimed by a participant;

- any allowances that are, or will be, or which are anticipated to be claimed by a participant;

- any exemptions that are, or will be, or which are anticipated to be claimed by a participant;

- any tax credits, including foreign tax credits, that are, or will be, or which are anticipated to be claimed by a participant; and

- any deferral of the receipt or accrual of income claimed or included.

SARS (2010:12) also prescribes that a tax benefit is calculated by considering the tax benefit derived over the period of the arrangement. As a result, annual recurring tax benefits will be taken into account. Projected tax flows over the period of the arrangement are taken into account on a nominal basis, i.e. they are not discounted (except in the case of section $80 \mathrm{M}(1)(e))$.

The next paragraph will address the term 'any', which is contained in the section $80 \mathrm{~T}$ definition of 'tax benefit'.

\subsection{Any}

The ordinary meaning of the word 'any' is as follows:

Any (adjective) indefinitely large

It is submitted that the insertion of the word 'any' has the effect of potentially including an indefinitely large number of routine transactions. In Hayne and Co v. Kaffrarian Steam Mill Co Ltd (1919) (at paragraph 371) and in CIR v. Ocean Manufacturing Ltd (1990) (at paragraph $618 \mathrm{H}$ ), it has been held that in its natural and ordinary sense (unless restricted by the context) 'any' is an indefinite term that includes all of the things to which it relates.

De Koker (2010:par 25.71) concurs that the word 'any' is a word of wide and unqualified generality. It may be restricted by the subject matter or the context, but prima facie it is unlimited. He further states that unless the context requires differently, it should be given a wide meaning. In terms of section $80 \mathrm{~N}(\mathrm{l})$, a 'plain-vanilla' arrangement is excluded if it is

a) a loan, advance or debt in terms of which-

i) the borrower receives or will receive an amount of cash and agrees to repay at least the same amount of cash to the lender at a determinable future date; or

ii) the borrower receives or will receive a fungible asset and agrees to return an asset of the same kind and of the same or equivalent quantity and quality to the lender at a determinable future date;

b) a lease; 
c) a transaction undertaken through an exchange regulated in terms of the Securities Services Act, 2004 (Act No. 36 of 2004); or

d) a transaction in participatory interests in a scheme regulated in terms of the Collective Investment Schemes Control Act, 2002 (Act No. 45 of 2002).

Section $80 \mathrm{~N}$ (2) contains 'stand-alone' requirements that must first be met in order for an arrangement to be excluded. If the arrangement is directly or indirectly dependent upon any other arrangement, the stand-alone requirement is not met and the arrangement is potentially reportable. Furthermore, section $80 \mathrm{~N}$ (3) negates the exclusions if the main (or one of the main) benefits was to obtain or enhance a tax benefit.

Fortunately, in terms of subsection (4), the Minister may determine an arrangement to be an excluded arrangement by notice in the Gazette, if he or she is satisfied that the arrangement is not likely to lead to an undue tax benefit. The Minister has excluded by way of notice in the Government Gazette (nr 30941 of 1 April 2008, Volume 514) any arrangement where the tax benefit from the arrangement:

- does not exceed Rl million; or

- is not the main or one of the main benefits of the arrangement.

SAICA (2007a) notes that it considers the scope of section 80M to be 'too wide and that it affects an absurd amount of routine transactions'. Even though the Minister has excluded arrangements where the tax benefit does not exceed Rl million, some taxpayers could easily exceed this cut-off amount with just a few routine transactions. To this end, SAICA (2007a) has proposed the inclusion of numerous specific transactions in the section $80 \mathrm{~N}(1)$ list of exclusions, as they are unlikely to lead to an undue tax benefit (refer to TABLE 1).

SARS (2010:11) concedes that the strict interpretation of 'tax benefit' will result in many everyday transactions falling within the ambit of a 'tax benefit', leading to uncertainty for taxpayers applying legitimate tax planning. It is, however, not the intention that routine transactions, for example, the purchase of stationery or the payment of salaries, which are incurred in the ordinary course of business, should be disclosed to SARS. The 'main or one of the main benefits' test is aimed at eliminating the need to disclose such routine transactions to SARS, whereas the $\mathrm{Rl}$ million threshold test introduces a de minimis rule.

However, as will be discussed below, the 'main benefit' requirement is subjective and difficult to comply with. It is therefore submitted that the section $80 \mathrm{~N}$ (1) list of plain-vanilla, excluded transactions should be extended to also include other routine, operating transactions such as the acquisition of any asset, trading stock, consumables and services on credit.

TABLE 1 is largely based on SAICA's recommendations to SARS and proposes the following list of excluded transactions: 
TABLE 1: Proposed extended list of excluded transactions

\begin{tabular}{|c|c|c|}
\hline Transaction & Description of transaction & Reason for exclusion \\
\hline $\begin{array}{l}\text { 1. Acquisition of any asset, } \\
\text { trading stock, consumables } \\
\text { and services on credit. }\end{array}$ & $\begin{array}{l}\text { - Expense is deductible in } \\
\text { terms of the general } \\
\text { deduction formula or } \\
\text { another specific } \\
\text { allowance. }\end{array}$ & $\begin{array}{l}\text { - These items generally } \\
\text { comprise trade debts and } \\
\text { form the basis of the } \\
\text { majority of transactions } \\
\text { between suppliers and } \\
\text { customers. } \\
\text { - This does not give rise to } \\
\text { an undue tax benefit. }\end{array}$ \\
\hline $\begin{array}{l}\text { 2. Acquisition of fixed } \\
\text { property, including fixed } \\
\text { property acquired with the } \\
\text { purpose of earning rental } \\
\text { income. }\end{array}$ & $\begin{array}{l}\text { - The property can be } \\
\text { financed by a mortgage } \\
\text { bond or other form of } \\
\text { financing. }\end{array}$ & $\begin{array}{l}\text { These items usually } \\
\text { comprise long-term } \\
\text { finance of an asset } \\
\text { acquired. } \\
\text { - This does not give rise to } \\
\text { an undue tax benefit. }\end{array}$ \\
\hline $\begin{array}{l}\text { 3. Acquisition of household } \\
\text { items and motor vehicles, } \\
\text { motor cycles and other } \\
\text { personal assets. }\end{array}$ & - & $\begin{array}{l}\text { - This does not give rise to } \\
\text { an undue tax benefit. }\end{array}$ \\
\hline 4. Various credit facilities & 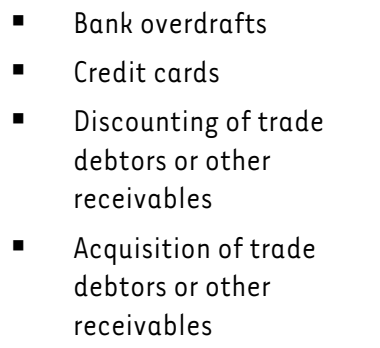 & $\begin{array}{l}\text { - These do not give rise to } \\
\text { an undue tax benefit. }\end{array}$ \\
\hline
\end{tabular}

Source: Authors'summary, largely based on SAICA (2007a).

The next paragraph will examine the meaning of the word 'assumed' which is contained in the introductory requirement of section $80 \mathrm{M}(1)$.

\subsection{Assumed}

Section $80 M(1)$ states that an arrangement is a reportable arrangement if any tax benefit is or will be derived or is assumed to be derived by any participant by virtue of that arrangement. The ordinary meaning of the word 'assume' is as follows:

Assume (verb): $\quad$ accept as true without proof or take responsibility or control

Based on the ordinary meaning of the word, it is clear that someone must take responsibility for establishing whether or not a tax benefit has arisen. It is unclear, though, upon whom this responsibility to establish the tax benefit will rest. Will SARS assume that a tax benefit was obtained by the participant, or must the taxpayer make that assumption? 
Firstly, the definition of a participant must be considered (which will be addressed in greater detail in a subsequent paragraph). A 'participant' in relation to a reportable arrangement is defined in section $80 \mathrm{~T}$ as:

(a) any promoter; or

(b) any company or trust which directly or indirectly derives or assumes that it derives a tax benefit or financial benefit by virtue of a reportable arrangement.

Part (b) of this definition has been slightly reworded in the current section 34 version of the TAA: the reference to 'reportable arrangement' has been amended to 'arrangement'. This was done as the definition of 'participant' as a whole was altered so as to be in relation to any 'arrangement' - not merely a 'reportable arrangement'.

Secondly, the definition of a 'financial benefit' is also contained in section $80 \mathrm{~T}$ and means any reduction in the cost of finance, including interest, finance charges, costs, fees, and discounts in the redemption amount. From the above definitions, it would seem that the participant has to make the assumption that a tax benefit was obtained, as the definition of a participant includes the phrase 'any company or trust which directly or indirectly assumes that it derives'. In this case, 'it' refers to the company or trust.

However, based on the arguments set out below, it is submitted that this is not the case - the Commissioner will have to assume that a tax benefit was derived. Applying the GAAR principles and court cases might assist in ascertaining on whom the burden of proof lies.

Clegg and Stretch (2010:par 26.3.3) state that is incumbent upon the Commissioner to show, on a balance of probabilities, that a tax benefit has arisen as a consequence of an arrangement as defined, before the specific terms of section 80A (one of the GAAR provisions) can even be considered. Cilliers (2008:104) places the burden of proof on the Commissioner, stating that:

\footnotetext{
A tax-avoider's goal is always primarily to secure an advantage for himself, even if his action should happen to be accompanied by an attitude of insouciance or one-upmanship towards the fiscus. At any rate, it is submitted, the onus in this regard must rest on the fiscus. To place the onus on the taxpayer in this context would be absurd.
}

De Koker (2010:par 19.5) submits that in order for the Commissioner to show that a tax benefit has indeed arisen, it is firstly necessary for him to establish and show what arrangement would otherwise have been entered into to produce the commercial result and the resulting tax consequences. Clegg and Stretch (2010:par 26.3.3) concur that it is not enough for the Commissioner simply to aver that a tax benefit has arisen - he must be sufficiently clear in his mind as to the nature of the alternative arrangement, to quantify the benefit.

Another point to bear in mind is the onus of proof as determined by section 82 of the Act. According to section 82, the burden of proof as to exemptions, deductions, abatements, disregarding or exclusions shall be upon the taxpayer. This suggests that the onus to disprove a tax benefit is likely to be placed on the taxpayer. This opinion is strengthened by the fact that the RA provisions contain no special presumption to indicate otherwise. Note that section 82 has been repealed; the TAA now places a similar burden of proof on the taxpayer in section 102(1) of the TAA. However, due to the fact that at the time the survey was conducted (in 2011) the provisions of the TAA were not yet enacted, section 82 of the Act is referred to throughout this article.

Meyerowitz, Emslie and Davis (2007:160) are of the opinion that the burden of proof must be placed on the Commissioner, and state that: 
With respect it is also our view that although section 82 of our Act casts the onus upon the taxpayer to prove the assessment to be wrong he will have discharged this onus if the Court accepts that the requirements of section $80 \mathrm{~A}$ (other than the misuse or abuse provisions) are not met, and it is then for the fiscus to convince the court that the taxpayer has misused or abused the relevant provisions.

In respect of the GAAR provisions, section $80 \mathrm{G}$ contains a presumption test. Once it has been established that an avoidance arrangement exists, section $80 \mathrm{G}(\mathrm{l})$ creates a presumption that it was entered into or carried out for the sole or main purpose of obtaining the tax benefit identified. The party obtaining that tax benefit may rebut that presumption by proving that obtaining a tax benefit was not the sole or main purpose of the avoidance arrangement.

In SIR v. Gallagher (1978), the court found that the section 80 g presumption placed a heavy burden of proof on the taxpayer, since the mere assertion by him that his purpose was not the avoidance of tax does not carry a great amount of weight. The taxpayer has to be able to point to some compelling reasons for entering into the arrangement, but the court must also be satisfied that the tax benefit was not the sole or main purpose. Clegg and Stretch (2010:par 26.3.4) submit that the courts must take an objective view of the facts and circumstances (which includes the ipse dixit of the taxpayer) to determine the actual purpose of the transaction.

It is unnecessary for a taxpayer to prove any point beyond a reasonable doubt or even for him to be faced with too high a standard of proof. Furthermore, the onus is discharged if the court has no reason to disbelieve the taxpayer and his evidence is not contradicted by objective facts. On the other hand, mere statements not corroborated by evidence are hardly sufficient to discharge the onus (De Koker, 2010:par 19.6).

In light of the above discussion, it would seem that the Commissioner must assume that a tax benefit was obtained by the participant before invoking the RA provisions. The onus to disprove this assumption will probably rest on the taxpayer. This argument is substantiated by the following statement made by SARS (2010:7):

The onus is on the participant to an arrangement to determine whether it needs to be disclosed to SARS.

SAICA (2007b) contends that the words 'assumed to be derived' is meant to cover situations where it is uncertain whether any tax benefit would flow. In such a case, SAICA suggests that the words 'assumed to be derived' be replaced by 'may be derived'. Furthermore, it is SAICA's view that it is a factual enquiry whether a tax benefit is or will be derived. This article concurs with SAICA's submission.

However, the Draft Guide states that the assumed tax treatment of an arrangement is apparent from the agreements as well as from the financial model (if any) which accompanies the arrangement (SARS, 2010:9). It further states that there is normally consent among the parties as to what these assumed tax benefits are, as they sign off on the agreements that underpin the model.

According to SARS, there is little room for debate as to what is meant by 'assumed' (SARS, 2010:9). However, SAICA notes that not all parties to these transactions are given insight into the financial models contained in these arrangements (SAICA, 2010a). It is therefore possible that a participant, for example a company, may not be aware of the assumed tax treatment of the arrangement other than to the extent that it directly has an impact on the tax liability of that company or trust. 
Furthermore, the Draft Guide requires a participant to calculate the tax benefit of the arrangement by taking into account the assumed tax effect in the hands of each participant and comparing this with the position had the arrangement not been entered into (SARS, 2010:11). Again, SAICA (2010a) notes that not all parties might be privy to the financial models that underpin these arrangements, and therefore may not be aware of the assumed tax effect in the hands of each participant other than to the extent that it directly has an impact on the tax liability of that company (or trust). That participant will thus be unable to determine the assumed tax effect in the hands of each participant and will be unable to make the required comparison.

Legal firm Cliffe Dekker Hofmeyr (2010:4) concurs and deems this problem to be an obvious one. They note that in a complex transaction, for example, many of the participants may not necessarily be aware who the other parties are, and may not know which parties may or may not have a reasonable expectation of a pre-tax profit, for example.

SARS (2010:11) cautions that in order to prevent exposure to a Rl million penalty, all participants to such arrangements should consider not only their own, but other parties' tax benefits. However, it is submitted that SAICA's view is correct and that SARS should specifically address circumstances where not all the parties are given insight into the financial models contained in the arrangements. This will assist in ensuring that participants will not be expected to make assumptions relating to arrangements to which they are not fully privy.

To summarise: in light of the GAAR provisions, it seems that the burden of proof rests on the Commissioner to establish whether a tax benefit has arisen. The section 82 onus to disprove this assumption will probably rest on the taxpayer. This argument is substantiated by SARS's view that the onus is on the participant to determine whether the arrangement needs to be disclosed to SARS. Even though SARS is of the opinion that the assumed tax treatment of an arrangement is apparent from the agreement and financial models (if any), it was submitted that SARS should specifically address circumstances where not all the parties are given insight into the financial models contained in the arrangements. The next paragraph will address the meaning of the terms 'participant and promoter', as the disclosure obligation rests on these persons.

\subsection{Participants and promoters}

\subsubsection{Participant}

As was previously stated, a participant in relation to a reportable arrangement is defined in section 80 T so as to mean:

(a) any promoter; or

(b) any company or trust which directly or indirectly derives or assumes that it derives a tax benefit or financial benefit by virtue of a reportable arrangement.

\subsubsection{Promoter}

The section $80 \mathrm{~T}$ definition of a promoter in relation to a reportable arrangement means

any person who is principally responsible for organising, designing, selling, financing or managing that reportable arrangement.

The ordinary meaning of the word 'promoter' is as follows: 
Promoter (noun):

a supporter of a cause or aim; the organiser.

The definition of a promoter did not appear in the former section 76A (the precursor to the 2006 RA provisions). Due to the fact that SARS (2005) referred to the international position of countries such as the USA and the UK when it introduced the RA provisions, one could infer that the concept of a promoter originated from the legislation of these countries. SAICA (2008) is of the opinion that SARS has introduced legislation that is unsuitable for the South African market, for the following reasons:

- The market for these types of products (or arrangements) is vast in the UK and the USA, whereas in South Africa the market is extremely small or limited. As a result, targeting these types of activities becomes difficult.

- It was the practice of professional advisors based in the UK and the USA to deliberately develop extensive tax practices that had as their main objective the development, marketing and implementation of so-called 'tax products'. This marketing included call centres devoted to 'cold calling' potential clients or targets. This practice is in contrast with the practices of the majority of professional advisors based in South Africa.

The UK definition of a promoter is contained in section 307 of the United Kingdom Finance Act that deals with notifiable arrangements (the UK equivalent of South Africa's reportable arrangements). Section 307 defines a promoter as follows:

(a) in relation to a notifiable proposal, if, in the course of a relevant business-

(i) he is to any extent responsible for the design of the proposed arrangements, or

(ii) he makes the notifiable proposal available for implementation by other persons, and

(b) in relation to notifiable arrangements, if he is by virtue of paragraph (a) (ii) a promoter in relation to a notifiable proposal which is implemented by those arrangements or if, in the course of a relevant business, he is to any extent responsible for -

(i) the design of the arrangements, or

(ii) the organisation or management of the arrangements.

The 'relevant business' (which is defined in section 307(2) of the UK Finance Act) mentioned above refers to any trade, profession or business that involves the provision of tax services or is carried out by a bank or a securities house. Essentially, the definition excludes persons in respect of whom certain tests, viz. the 'benign tax advice', 'non-tax advisor' or 'ignorance test', apply (SAICA, 2008).

The UK and South African definitions of a promoter differ slightly. Unlike the current South African definition, professional tax advisors are excluded from the UK definition under certain circumstances. In addition, the South African definition is significantly broader than the UK definition by virtue of the insertion of the word 'or' in the South African definition.

SAICA (2008) suggests that the South African definition be amended as follows in order to bring it in line with the UK definition:

A promoter in relation to a reportable arrangement means any person who is principally responsible for

(a) designing and selling or

(b) designing or selling and organising or managing that reportable arrangement. 
Furthermore, SAICA (2008) does not believe that the person responsible for managing the transaction should be included in the definition of promoter. Banks often appoint an outside party, unrelated to the transaction, to act as 'facility agent' or 'inter-creditor agent'. If that person played no part in setting up the transaction and is merely there to ensure that the interests of the parties are adequately catered for, there is no reason to include them in the definition of promoter. It is submitted that SAICA's recommendation is correct and that, as an alternative to the above proposed definition, the word 'managing' should be deleted from the current section 80T definition of a promoter.

SARS concedes that, by definition, 'promoter' is a very wide term (SARS, 2010:26). The Draft Guide recommends that if any doubt exists as to whether a particular participant is the promoter, a letter should be obtained from the disclosing promoter as contemplated in section 800 (3). SAICA (2010a) is of the opinion that the Draft Guide is incomplete without a detailed discussion of the various parties who are required to disclose reportable arrangements. It is therefore proposed by SAICA, and, again, this article concurs, that SARS should also specifically address the following circumstances where:

- the promoter is not based in South Africa;

- the promoter is a member of a profession, such as an accountant or lawyer; and

- there is no promoter, for example in-house arrangements.

It is important, however, to take cognisance of the client/attorney privilege if the promoter is a lawyer. Her Majesty's Revenue and Customs (HMRC) office provides guidelines in such cases (HMRC, 2011:par3.8), as schemes promoted by lawyers fall within the scope of the disclosure rules in the same way as for other promoters. The HMRC states that where an advisor who would ordinarily be a promoter is prevented by reason of legal professional privilege from providing any of the information needed to make a full disclosure, that advisor has no obligation to make a disclosure.

Furthermore, unless there is another promoter who has an obligation to disclose the scheme, it must be disclosed by any person in the UK who enters into any transaction forming part of it. It is noted that the client of the lawyer has the option of waiving any right to legal privilege. If legal privilege is waived the lawyer is required to disclose. Recently, in $R$ (Prudential p/c \& Anor) $v$. Special Commissioner of Income Tax \& Anor (2013), the UK Supreme Court handed down its judgment on extending legal professional privilege to chartered accountants. It ruled that the privilege should not be extended to clients of non-legally qualified tax advisers, but that the matter should be looked at by Parliament.

In South Africa, taxpayers may lawfully refuse to supply information to the Commissioner which is subject to legal professional privilege. Law firm Edward Nathan Sonnenbergs (2011:11) explains that, in principle, legal professional privilege applies where a person seeks legal advice from an attorney or advocate on a professional basis (the so-called 'advice privilege') or where advice is sought in anticipation of litigation from an attorney or advocate acting in a professional capacity (the so-called 'litigation privilege').

Noteworthy is the fact that legal privilege is extended only to qualified attorneys or advocates of the High Court. However, it does not follow that simply by virtue of the person being an advocate or an attorney, legal privilege will be afforded to everything said by or to the advocate or attorney; he or she must have acted as an advisor in a professional capacity (Perry, 2008). Therefore, before legal professional privilege can be claimed, any communication between a 
client and attorney or advocate must have been made to a legal advisor acting in a professional capacity, in confidence, for the purpose of pending litigation or for the purpose of obtaining professional advice (Croome, 2007:52).

It should be pointed out that under existing statutory provisions tax advice supplied by an accountant to a client is not subject to legal professional privilege (Edward Nathan Sonnenbergs, 2011:14). It should be cautioned that where an accountant provides tax advice (including advice on the structuring of arrangements that might fall within the ambit of the reportable arrangements provisions) such advice is not protected by legal professional privilege.

Edward Nathan Sonnenbergs (2011:14) contends that, if called on by SARS, such advice would (on the face of it) be required to be supplied to SARS. This could place attorneys and advocates in a preferential position in advising clients on tax matters. It should be noted that the TAA currently does not contain a provision extending legal professional privilege to accountants who act as tax advisors.

It is therefore submitted that SARS should take the client/attorney privilege into consideration so as to adequately address the scenario where the promoter is also a lawyer. It is furthermore proposed that legal professional privilege should also be extended to accountants who act as tax advisors.

The next subparagraph will address the term 'directly or indirectly' which is also contained in the section $80 \mathrm{~T}$ definition of a 'participant'.

\subsubsection{Directly or Indirectly}

Part (b) of the section $80 \mathrm{~T}$ definition of a 'participant' (in relation to a reportable arrangement) refers to any company or trust that directly or indirectly derives or assumes that it derives a tax benefit or financial benefit by virtue of that arrangement. The ordinary meaning of the words 'directly' and 'indirectly' are as follows:

Directly (adverb): $\quad$ in a direct manner; exactly

Indirectly (adverb): $\quad$ not direct; not going straight to the point; not straightforward or honest; devious

In the case of SIR v. Consolidated Citrus Estates Ltd (1967) Galgut JA explained [at paragraph 148] that:

Directly appears to have been deliberately added in order to serve some purpose that the Legislature had in mind. The purpose, I think, was to postulate that the connection between the taxpayer's incurring the expenditure and the object for which it was incurred ... should be direct, i.e. straight and close, not devious and remote. (emphasis added)

Thus, the word 'directly' implies an exact, straight and close manner. The word 'indirectly' implies something devious and remote, or not straightforward. As the words 'directly' and 'indirectly' are antonyms, by using them simultaneously, the scope of section $80 \mathrm{M}$ (1) has been widened. An arrangement can therefore directly or indirectly cause a benefit to be derived.

The next paragraph will examine the meaning of the words contained in section $80 \mathrm{~N}(3)$, which was mentioned earlier in this article. 


\subsection{Section $80 N(3)$ Terminology}

Of specific interest is the wording of section $80 \mathrm{~N}(3)$, namely that the excluded list of section $80 \mathrm{~N}(1)$ does not apply to any arrangement that is entered into with the main purpose of obtaining or enhancing a tax benefit. The meaning of the terms 'main purpose', 'enhance' and 'undue' will now be analysed.

\subsubsection{Main purpose}

The ordinary meaning of the word 'purpose' is as follows:

Purpose (noun): $\quad$ the reason for which something is done or for which something exists; the object or aim in doing something.

Purpose (verb): $\quad$ have as one's objective; to intend to do something

Tax avoidance is based on the purpose of the arrangement or the person undertaking the arrangement as the essential distinction between permissible tax planning and impermissible tax avoidance. The word 'purpose' appears in the opening words of section $80 \mathrm{~A}$ of the GAAR provisions:

An avoidance arrangement is an impermissible avoidance arrangement if its sole or main
purpose was to obtain a tax benefit ... (emphasis added)

Note the clear reference to the purpose of the arrangement itself (by using the determiner 'its') and not to the purpose of the taxpayer. Based on Lord Denning's judgement in Newton v. COT (1958), purpose in this sense means not intention, but the effect that it sought to achieve, i.e. the end accomplished or achieved. It is thus not a subjective test, but an objective one.

De Koker (2010:par19.6) contends that the words 'purpose' and 'effect' have usually been construed in case law as a composite term. If an arrangement has a particular purpose, then that will be its intended effect (i.e. the intention of the taxpayer is irrelevant). If an arrangement has a particular effect, then that will be its purpose. Oral evidence to show that it has a different purpose or different effect to that which is shown by the arrangement itself is irrelevant to the determination of the question whether the arrangement has (or purports to have) the purpose or effect of in any way altering the incidence of income tax.

However, in the RA provision of section $80 \mathrm{~N}(3)$ the wording is slightly different. Section $80 \mathrm{~N}(3)(a)$ states that subsection (1) does not apply to any arrangement that is entered into with the main purpose of obtaining or enhancing a tax benefit.

Section $80 N(3)$ thus refers to the situation where the arrangement was entered into with the main purpose of obtaining or enhancing a tax benefit. It refers, therefore, to the intention of the taxpayer (in this case the participant to the arrangement) and not to the effect that it sought to achieve. It is therefore submitted that the proper test to apply in this case is a subjective test, and not an objective test.

In the case of SIR v. Geusteyn, Forsyth and Joubert (1971), a subjective test was applied. In the case of SIR v. Gallagher (1978), the subjective test took as its criterion the purpose that those carrying out the scheme intended to achieve by it. Thus, the question to be asked is: what was in the mind of the taxpayer who entered into the transaction?

It was determined in CIR v. Conhage (1999) that where a taxpayer is presented with a choice between two single transactions as alternative methods of achieving the same commercial end 
result, but that have quite different tax consequences - for example, the choice between lease finance and suspensive sale finance of a moveable asset - it is considered that, irrespective of which transaction type is selected, the main purpose of that transaction cannot be the obtaining of a tax benefit.

This judicial approach emanated from the so-called principle of choice expounded in $I R C v$. Duke of Westminster (1936), where Lord Tomlin expressed the view that taxpayers are entitled to order their affairs so the tax attaching is less than it otherwise would be. The choice principle proceeds on the footing that the taxpayer is entitled to create a situation by entering into a transaction that would attract tax consequences for which the Act makes a specific provision. The validity of the transaction is not affected merely because the tax consequences that it attracts are advantageous to the taxpayer and he enters into the transaction deliberately with a view to gaining that advantage.

In the Australian context, the choice principle was extended further when the court indicated, in Cridland v. FCOT (1977), that it was not confined to cases where the Act offered two alternative bases of tax. A taxpayer who deliberately creates a situation because of tax consequences specifically provided by the Act is not caught by the new anti-avoidance provision.

In the South African context, the choice principle was affirmed by the Conhage case. The court confirmed that where two alternative methods of achieving largely the same commercial results are available to a taxpayer, his purpose in choosing the alternative which carries the more advantageous tax consequences amounts to a subsidiary or incidental purpose, and not the main or sole purpose of the transaction. The main purpose remains that of achieving the commercial result.

In ITC 1636 (60 SATC 267) Kroon J cited various cases to ascertain the meaning of 'solely or mainly' in the context of section 103(1). The first case that he referred to was ITC 983 (25 SATC $55)$, where the court dealt with section $90(1)(b)$ of the Income Tax Act No. 31 of 1941. This provision contained words similar to those in section 103(1), viz. 'solely or mainly for the purpose'. The court stated the following (at page 58):

... for the section to operate the avoidance of tax must at least have been the principal purpose of the taxpayer. In the present case the court is satisfied that although the avoidance or reduction of tax was one of the purposes, it was not the main purpose. The main purpose was to obtain a production unit which could go into immediate operation, as indeed the Appellant company did.

Thereafter, Kroon J referred to ITC 1307 (42 SATC 147), which dealt with a previous version of section 103(1) that contained the words 'the sole or one of the main purposes'. The court investigated the meaning of the word 'main' and found it to mean [at page 153]:

... principal, major and most important, and the ascertainment of a main purpose involves a weighing against each other of the various purposes of a scheme. In a case such as the present, where at most two purposes have been suggested (a saving on income tax and a saving on estate duty), if one purpose preponderates over the other it cannot be said that the other is a main purpose.

Kroon J concluded that the mere fact that one purpose is regarded as not being of the same importance as another purpose does not preclude the former purpose from being one of the main purposes. He stated (at page 334) that:

It is not necessary, for more than one purpose to qualify for the epithet of 'main', that each of the purposes be of equal importance. Provided that a particular purpose, viewed by itself, is 
of sufficient importance to attract the description of 'main' in the sense of being a major inducing consideration, it matters not that another purpose featured more prominently.... In short, to qualify as the main purpose, the purpose in question must preponderate over any other purpose (or, possibly, at least be as important as any other purpose). (emphasis added)

Clegg and Stretch (2010:par 26.3.4) note that an issue which has never been considered by the courts is exactly how a main purpose is to be determined. The commercial consequences of a transaction may have both quantitative (i.e. numerical) and qualitative (i.e. business efficiency) components, whereas the tax benefit to be weighed in the balance is purely quantitative. The question then arises as to how one must give weight to qualitative consequences?

As indicated earlier by the Conhage case, single step arrangements with real substantive commercial advantages for the taxpayer will always have as its main purpose a non-tax benefit. In the case of multi-step transactions, however, there may be elements present where the commercial advantages are less clearly dominant, notwithstanding that they contribute to the overall commercial result.

Clegg and Stretch (2010:par 26.3.4) suggest that in such situations the question should be whether that particular step is commercially necessary in achieving the final commercial result or whether it could be dispensed with without affecting the commercial end. The authors submitted that if that step can be dispensed with, the main reason for its incorporation would be the tax benefit.

A final question to be addressed is determining the time the arrangement was entered into. Should the main purpose be determined at the time when the arrangement was implemented or when it was first conceived? In Ovenstone v. CIR (1980) Trollip JA delivered the judgment [at page 68] that:

even if the purpose or effect of [a] scheme when it is formulated is not to avoid liability for tax, it may have that effect or that may become one of the taxpayer's main purposes when he subsequently carries it out...

Thus, the purpose of a scheme when it is first formulated may not be to avoid tax but this may become the purpose at the time of implementation.

To summarise: determining the main purpose of an arrangement is problematic. The courts can look at the purpose of the arrangement itself by using an objective test. But the courts can also consider the intention of the taxpayer by implementing a subjective test, or the so-called choice principle. It was determined that in order for a purpose to qualify as the 'main purpose', it had to preponderate over any other purpose. Finally, the time when the main purpose of the arrangement is to be determined, seems to be a contentious point.

The next paragraph will discuss the meaning of the word 'enhance'.

\subsubsection{Enhance}

Section $80 \mathrm{~N}$ (3) refers to the enhancing of a tax benefit. The ordinary meaning of the word 'enhance' is as follows:

Enhance (verb): $\quad$ increase the quality, value or extent of. 
In order to enhance a tax benefit, it presupposes the existence of a tax benefit. This, in itself, is problematic, as was discussed in earlier paragraphs. One must therefore consider two things when interpreting the meaning of the word 'enhance'. Firstly, the existence of a tax benefit must be established, and, secondly, the value of that tax benefit has to increase after the arrangement was entered into. SARS identifies two methods for determining a tax benefit (SARS, 2010:10):

\section{Comparative method}

This is the method favoured by SARS. This test compares the situation where the parties did not enter into an arrangement (i.e. they did nothing) with the position following the implementation of an arrangement. The tax benefit is discounted over the period of the transaction to the date of the first cash flow of the arrangement, unless the participant is able to prove a more reasonable alternative method.

\section{Control transaction method}

The control transaction method compares the tax benefit obtained by the arrangement in question with the benefit that would have been obtained by a comparable transaction not considered to have been entered into to achieve a tax benefit. If the participants, or SARS, wish to rely on the control transaction method to prove that a tax benefit had or had not been attained, they must justify why the proposed method would be more appropriate than the comparative method.

It is submitted that the above methods could also be used to determine whether or not a tax benefit was enhanced. For example, by applying the 'comparative method' to an existing tax benefit, the participant could compare the position before and after the arrangement was entered into. The value of the tax benefit is therefore compared before and after the implementation of the arrangement in order to determine whether it was enhanced.

The next paragraph will consider the meaning of the word 'undue'.

\subsubsection{Undue}

Section $80 \mathrm{~N}$ (4) of the Act states that the Minister may determine an arrangement to be an excluded arrangement by notice in the Gazette, if he or she is satisfied that the arrangement is not likely to lead to an undue tax benefit. The ordinary meaning of the word 'undue' is as follows:

Undue (adjective) excessive or disproportionate; unjustifiable; improper

The dictionary definition seems to imply that an undue tax benefit, obtained by the participant to the arrangement, is excessive or unjustifiable. How, exactly, should the excessive portion be determined and by whom?

SAICA (2004) states that the term 'undue' attempts to second-guess the intention of the legislature. This statement is explained by the fact that in a South African tax context the concepts of tax evasion and tax avoidance already exist. 'Undue' introduces a new concept that implies that even where there is no question of tax evasion or tax avoidance, and where there is undisputed compliance with tax law, it must now be decided whether or not a legitimate tax effect of the legislation is 'undue'.

SAICA (2004) suggests that the terms 'undue tax benefit' be replaced with the term 'reporting requirement'. This article concurs, as the term 'reporting requirement' should achieve the 
intention of including and excluding specially Gazetted arrangements without making use of problematic terminology.

However, the yardstick that SARS will employ to determine the excessive amount, is not yet evident. It is unclear whether the Rl million exclusion in section $80 \mathrm{~N}(4)$ is meant to be the yardstick.

\subsection{Conclusion}

Having examined a selection of problematic wording contained in the RA provisions, it was necessary to test the research findings of the literature review. This was done by means of a survey conducted among tax partners at a sample of leading audit and legal firms in South Africa. The results of this empirical study are analysed in the remainder of this article.

\section{RESULTS OF THE EMPIRICAL STUDY}

\subsection{Background to the sample selection}

The unit of analysis and the population consist of highly qualified professionals who are experts in the field of tax. As was the case with Venter and Stiglingh's (2006a; 2006b) study, the purpose of the survey conducted was to test the conclusions reached in the literature study against the opinions of tax specialists in South Africa. A similar methodology is adopted in this study, but with the following differences in the approach:

\section{(a) Accounting lecturers and partners specialising in technical accounting matters}

In Venter and Stiglingh's survey (2006a:105; 2006b:113), the accounting lecturers and the partners specialising in technical accounting matters were chosen, as they were actively involved with accounting standards on a day-to-day basis and were expected to have in-depth knowledge of the accounting requirements of IAS 12 Income Taxes (which interacts with the (former) Secondary Tax on Companies (STC) requirements of the Act). However, in this study, the focus is entirely on a taxation topic, viz. the RA provisions. An in-depth accounting knowledge is therefore not necessary to understand this tax topic.

The RA provisions were excluded from SAICA's list of examinable pronouncements for prospective chartered accountants (SAICA, 2010b; 2011). It was therefore considered that these provisions would most likely not be a priority for accounting academics. Accordingly, university lecturers and accounting partners were not included in the sample for this study, as their inclusion would probably not have resulted in an increase in the quality of answers received to the questionnaire.

\section{(b) Tax partners at le ading audit and legal firms}

As was the case in Venter and Stiglingh's study, tax partners are included in this study, as they are indeed expected to be actively involved with taxation legislation and should have in-depth knowledge of compliance with the RA provisions. Tax partners at audit, as well as legal, firms were included in the survey. However, whereas Venter and Stiglingh's sample included seven tax partners, the sample in this study includes 40 tax partners from audit and legal firms. The basis for the selection of the sample is explained below. 


\subsection{The sample}

\subsubsection{Non-probability sampling}

This study made use of non-probability sampling, and, more specifically, judgement sampling. Judgement sampling is one of the two types of purposive sampling (the other type being quota sampling). According to Cooper and Schindler (2011:385), judgement sampling occurs when a researcher selects sample members to conform to some criterion.

It was noted earlier that one of the ways to qualify for the non-disclosure of an arrangement is if the tax benefit does not exceed Rl million (section $80 \mathrm{~N}(4)$ ). It would be expected that larger companies would fall within the ambit of the RA provisions more often, as they are more likely to conclude transactions with tax benefits exceeding Rl million.

Therefore, it could be argued that the persons best able to address the statements in the questionnaire are those tax professionals who are actively involved in complex, technical tax matters and who are involved in providing tax advice for larger companies. Moreover, tax partners or directors are frequently individuals who have obtained advanced tertiary qualifications and who have many years of practical experience in complicated tax issues. They are therefore best suited to provide commentary on the subjective interpretation of tax provisions.

Based on the above arguments, the criteria for the selection of the sample are

- Tax partners or directors at

- Leading audit and legal firms.

As will be seen from the next paragraph, the sample selected includes all of the audit firms that audit companies listed on the Johannesburg Stock Exchange ('JSE') as well as the 10 largest audit firms globally. The sample also includes the 10 largest South African legal firms. Nonprobability sampling, specifically judgement sampling, is therefore considered to be both appropriate and adequate for this present study. This is also in line with the methodology followed by Venter and Stiglingh, wherein the eight largest audit firms were identified.

\subsubsection{Audit firms selected for the sample}

This study comprises a sample of 30 audit firms (refer to Appendix 2 for an alphabetical listing of the firms included in the sample). These firms were selected on the following bases:

- A listing of the top 10 audit firms in the world, based on the (then) most recent available fee income figures (for 2009 and in US dollars), was obtained from World Accounting Intelligence (2011). All of the top 10 global firms have offices in South Africa. The so-called 'Big Four' audit firms are naturally included in this list.

- A list of JSE accredited auditors was obtained from the JSE website (JSE, 2011a; 2011b). This study only includes South African audit firms registered in terms of the Independent Regulatory Board for Auditors (IRBA).

- The final sample of audit firms (after removing duplicate entries in the above selections) is therefore a combination of the global top 10 audit firms and the JSE list of accredited auditors. 


\subsubsection{Legal firms selected for the sample}

This study also comprises a sample of 10 legal firms (refer to Appendix 2 for an alphabetical listing of the firms included in the sample). These firms were selected on the following basis:

- A listing of the 10 largest legal firms in South Africa, based on the most recent available number of attorneys in their employ (at the time when the survey was conducted), was obtained from Internet searches. Wikipedia (2011) combined the information of major South African legal firms by using data from their websites to compile a listing of the rankings.

\subsection{Background to the questionnaire}

The tax partners of the audit and legal firms in South Africa were identified either from information contained on the websites of the firms or by means of a telephone call to the firms to obtain the names and e-mail addresses of the relevant parties. Where a firm did not have a specialist tax partner or department, the questionnaire was sent to the contact partner with a request to forward it to the most appropriate (senior) individual in the firm.

The partners were initially contacted by a telephone call to determine their willingness to participate in the survey; those that could not be reached telephonically were contacted via email. The questionnaires were distributed to the parties by e-mail. Respondents returned the completed questionnaires via e-mail or fax (directly to the researcher).

\subsubsection{Composition of the questionnaire}

Another document, e-mailed in conjunction with the questionnaire, was included to present a general background on the topic. Due to the fact that the questionnaire included questions on SARS's Draft Guide model, an exact copy of the Draft Guide model was included in the background document, as well as the link to the original document on the SARS website.

The first part of the questionnaire (Part A) consisted of general questions about the profile of the respondent. The second part (Part B) contained 12 questions relating to the terminology in sections $80 \mathrm{M}$ to $80 \mathrm{~T}$ (of which nine are addressed in this article). The third part (Part C) consisted of 18 questions, which analysed the SARS Draft Guide model (which is beyond the scope of this article).

\subsubsection{Profile of respondents}

The profile of the respondents was as follows:

- $59 \%$ of the respondents are partners or directors at their firms, while $18 \%$ are tax managers. Where the tax partner was unable (for example due to time constraints) to complete the questionnaire, it was requested that the questionnaire be forwarded to an appropriate senior staff member. Senior staff members who did not hold office as tax partner, director or manager, but who had practical experience with the RA provisions, were grouped together in the category 'Other'; examples include the position of audit partner (where firms did not have a designated tax department), tax administrator and consulting counsel; 
TABLE 2: Profile of respondents

\begin{tabular}{lccc}
\hline & $\begin{array}{c}\text { Audit firms } \\
(n=12)\end{array}$ & $\begin{array}{c}\text { Legal firms } \\
(n=5)\end{array}$ & $\begin{array}{c}\text { Total } \\
(n=17)\end{array}$ \\
\hline Tax director & $\%$ & $\%$ & $\%$ \\
\hline Tax partner & 25 & 80 & 41 \\
Tax manager & 17 & 20 & 18 \\
\hline Other & 25 & 0 & 18 \\
\hline Total & 33 & 0 & 23 \\
\hline
\end{tabular}

Source: Authors' calculations

- $29 \%$ of the respondents have less than 10 years' experience in South African tax legislation, $24 \%$ have between 10 and 15 years' experience and $47 \%$ have more than 15 years' experience; and

- $53 \%$ of the respondents considered their knowledge of the RA provisions as 'good', $29 \%$ considered it to be 'fair', while $18 \%$ considered their knowledge to be 'poor'.

\subsubsection{Response rate}

In total, 40 questionnaires were distributed - 30 to audit firms and 10 to legal firms. The response rate in both categories is set out in TABLE 3 .

TABLE 3: Response rate

\begin{tabular}{lcc}
\hline & Actual number & Response rate \\
& ofresponses & $\%$ \\
Audit firms & 12 & 40 \\
Legal firms & 5 & 50 \\
Total responses & 17 & 43 \\
\hline
\end{tabular}

Source: Authors' calculations

Questionnaires that were not completed by the deadline were followed up with additional emails and/or telephone calls. Although one would usually prefer a higher response rate in empirical studies of this nature, it is not the intention of this study to acquire results that give a true cross-section of the population. Instead, this study relies on the quality of feedback received from the respondents; the majority $(71 \%)$ of respondents have at least 10 years of experience in South African tax legislation, while $82 \%$ considered their knowledge of the RA provisions as good to fair. In light of the expertise of the respondents, it can therefore be assumed that their responses are of great value and add credibility to the results. The response rate of $43 \%$ is accordingly considered to be adequate. 


\subsection{Statistical Summary of Results}

The tables below set out the results on the responses received to the questionnaire.

Question 1: Even though the Minister has excluded arrangements where the tax benefit does not exceed Rl million, some taxpayers could easily exceed this cut-off amount with just a few routine transactions. Do you agree with this statement?

TABLE 4: Results of Question 1

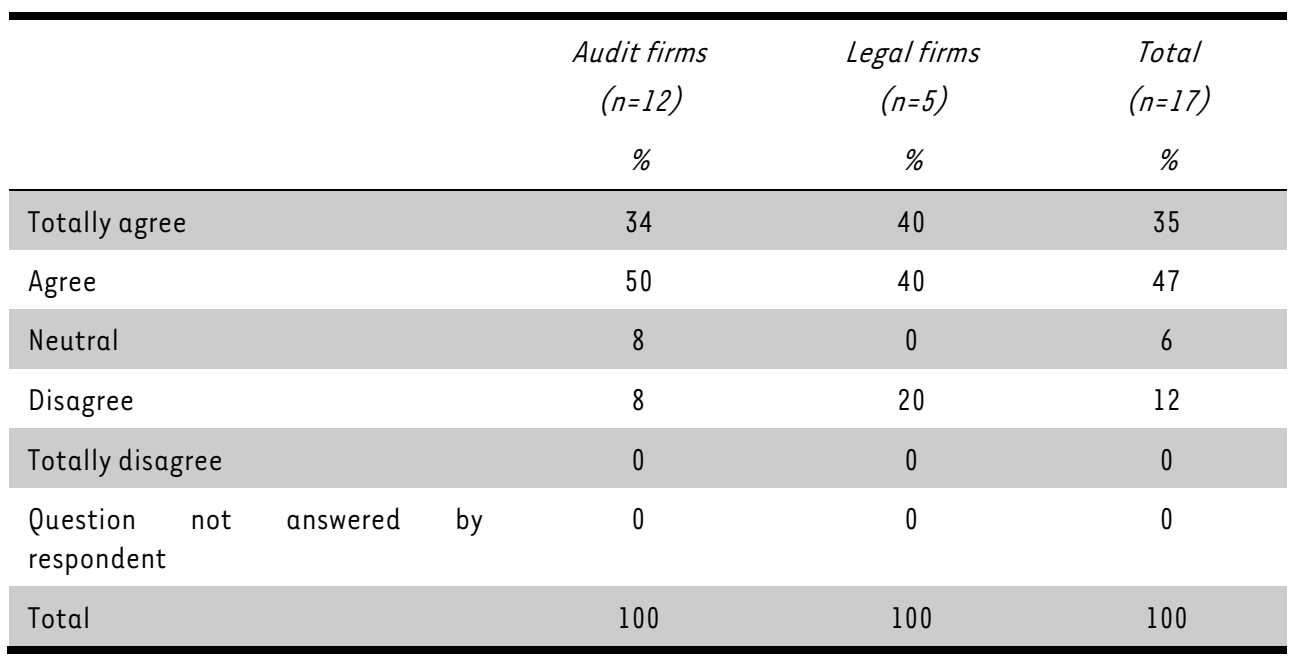

Source: Authors' calculations

A high percentage ( $82 \%)$ of the respondents agreed or totally agreed with the conclusions drawn from the literature study that even though the Minister has excluded arrangements where the tax benefit does not exceed Rl million, some taxpayers could easily exceed this cut-off amount with just a few transactions.

Question 2: If none of the section $80 \mathrm{~N}$ exclusions are applicable, the term 'any' in the definition of a 'tax benefit' is too wide and results in the cumbersome effect of ordinary, routine transactions becoming reportable. Do you agree with this statement? 
TABLE 5: Results of Question 2

\begin{tabular}{lccc}
\hline & $\begin{array}{c}\text { Audit firms } \\
(n=12)\end{array}$ & $\begin{array}{c}\text { Legal firms } \\
(n=5)\end{array}$ & $\begin{array}{c}\text { Total } \\
(n=17)\end{array}$ \\
& $\%$ & $\%$ & 12 \\
\hline Totally agree & 17 & 0 & 64 \\
\hline Agree & 58 & 80 & 12 \\
Neutral & 17 & 0 & 12 \\
\hline Disagree & 8 & 20 & 0 \\
\hline Totally disagree & 0 & 0 & 0 \\
\hline Puestion not answered by respondent & 0 & 0 & 100 \\
\hline Total & 100 & 100 & 0 \\
\hline
\end{tabular}

Source: Authors' calculations

The results of the questionnaire confirmed the conclusion drawn from the literature study, namely that the term 'any' in the definition of a 'tax benefit' is too wide. The majority of respondents $(76 \%)$ agreed or totally agreed that if none of the section $80 \mathrm{~N}$ exclusions are applicable, the definition of a 'tax benefit' results in the cumbersome effect of ordinary, routine transactions becoming reportable.

Question 3: The list of 'plain-vanilla' transactions in section $80 \mathrm{~N}$ (1) should be extended to include other routine, operating transactions which do not give rise to an undue tax benefit, such as the acquisition of any asset, trading stock, consumables and services on credit. Do you agree with this statement?

TABLE 6: Results of Question 3

\begin{tabular}{lccc}
\hline & Audit firms & Legal firms & Total \\
& $(n=12)$ & $(n=5)$ & $(n=17)$ \\
& $\%$ & $\%$ & 12 \\
\hline Totally agree & 17 & 100 & 82 \\
Agree & 75 & 0 & 6 \\
Neutral & 8 & 0 & 0 \\
Disagree & 0 & 0 & 0 \\
Totally disagree & 0 & 0 & 0 \\
\hline Puestion not answered by respondent & 0 & 100 & 100 \\
\hline Total & 100 & & $\%$ \\
\hline
\end{tabular}

Source: Authors' calculations 
An overwhelming majority (94\%) of respondents agreed or totally agreed that the list of 'plainvanilla' transactions in section $80 \mathrm{~N}$ (1) should be extended to include other routine operating transactions that do not give rise to an undue tax benefit. The results obtained from the empirical study confirm the research proposals made in the literature study, namely that the section $80 \mathrm{~N}(1)$ list of exclusions should be extended to also include, for example, the acquisition of any asset, trading stock, consumables and services on credit.

Question 4: The meaning of the requirement 'undue tax benefit' in section $80 \mathrm{~N}(4)$ is unclear, as neither the Act nor SARS provides clarity on how the 'undue' amount should be determined and by whom. Do you agree with this statement?

TABLE 7: Results of Question 4

\begin{tabular}{lccc}
\hline & Audit firms & Legalfirms & Total \\
& $(n=12)$ & $(n=5)$ & $\%$ \\
\hline Totally agree & $\%$ & $\%$ & 47 \\
Agree & 42 & 60 & 41 \\
Neutral & 42 & 40 & 6 \\
Disagree & 8 & 0 & 6 \\
Totally disagree & 8 & 0 & 0 \\
\hline Question not answered by respondent & 0 & 0 & 0 \\
\hline Total & 0 & 0 & 100 \\
\hline
\end{tabular}

Source: Authors' calculations

The results of the questionnaire confirmed the conclusion drawn from the literature study, namely that the meaning of the requirement 'undue tax benefit' in section $80 \mathrm{~N}(4)$, is unclear. The vast majority of respondents ( $88 \%$ ) agreed or totally agreed that as neither the Act nor SARS provides clarity on how the 'undue' amount should be determined and by whom, the meaning of the requirement is unclear.

Question 5: The introductory requirement of section $80 \mathrm{M}(1)$ states, inter alia, that an arrangement is reportable if any tax benefit is 'assumed to be derived by any participant'. Who do you consider must assume that a tax benefit is or will be derived? 
TABLE 8: Results of Question 5

\begin{tabular}{lccc}
\hline & $\begin{array}{c}\text { Audit firms } \\
(n=12)\end{array}$ & $\begin{array}{c}\text { Legal firms } \\
(n=5)\end{array}$ & $\begin{array}{c}\text { Total } \\
(n=17)\end{array}$ \\
\hline The Commissioner of SARS & $\%$ & $\%$ & $\%$ \\
Any participant to the arrangement & 17 & 40 & 24 \\
Question not answered by respondent & 75 & 60 & 70 \\
Total & 8 & 0 & 6 \\
\hline
\end{tabular}

Source: Authors' calculations

The majority of respondents ( $70 \%$ ) believe that the onus to assume that a tax benefit is or will be derived rests on any participant to the arrangement. Only $24 \%$ of respondents agreed with the results obtained from the literature study, namely that the onus to assume that a tax benefit is or will be derived lies upon the Commissioner of SARS. The inconsistent results might indicate an uncertainty as to who must bear the onus of making an assumption that a tax benefit is or will be derived. The results therefore appear to contradict the statement made by SARS (2010:9), i.e. that there 'is little room for debate as to what is meant by "assumed"'.

Question 6: Not all parties to a transaction are always given insight into the financial model contained in the arrangement and it is therefore possible that a participant may not be aware of the assumed tax treatment of the arrangement. Do you agree with this statement?

TABLE 9: Results of Question 6

\begin{tabular}{lccc}
\hline & $\begin{array}{c}\text { Audit firms } \\
(n=12)\end{array}$ & $\begin{array}{c}\text { Legal firms } \\
(n=5)\end{array}$ & $\begin{array}{c}\text { Total } \\
(n=17)\end{array}$ \\
& $\%$ & $\%$ & $\%$ \\
\hline Totally agree & 25 & 60 & 35 \\
\hline Agree & 75 & 40 & 65 \\
Neutral & 0 & 0 & 0 \\
Disagree & 0 & 0 & 0 \\
Totally disagree & 0 & 0 & 0 \\
Question not answered by respondent & 0 & 0 & 0 \\
Total & 100 & 100 & 100 \\
\hline
\end{tabular}

Source: Authors' calculations

The results of the questionnaire confirmed the conclusion drawn from the literature study, namely that it is possible that a participant may not be aware of the assumed tax treatment of the arrangement. All of the respondents (100\%) agreed or totally agreed with the research 
findings in the literature study, due to the fact that not all parties to a transaction are always given insight into the financial model contained in the arrangement. In light of the results of the questionnaire, the submission made in the literature study appears to be particularly relevant, namely that SARS should specifically address circumstances where not all the parties are given insight into the financial models contained in the arrangements. This will assist in ensuring that participants will not be expected to make assumptions relating to arrangements to which they are not fully privy.

Question 7: To cover situations where it is uncertain whether any tax benefit will flow, a more appropriate wording of section $80 \mathrm{M}(1)$ would be where the words 'assumed to be derived' are replaced by 'may be derived'. Do you agree with this statement?

TABLE 10: Results of Question 7

\begin{tabular}{lccc}
\hline & $\begin{array}{c}\text { Audit firms } \\
(n=12)\end{array}$ & $\begin{array}{c}\text { Legal firms } \\
(n=5)\end{array}$ & $\begin{array}{c}\text { Total } \\
(n=17)\end{array}$ \\
& $\%$ & $\%$ & $\%$ \\
\hline Totally agree & 8 & 20 & 12 \\
Agree & 34 & 60 & 41 \\
Neutral & 8 & 0 & 6 \\
Disagree & 42 & 20 & 35 \\
Totally disagree & 0 & 0 & 0 \\
Question not answered by respondent & 8 & 0 & 6 \\
\hline Total & 100 & 100 & 100 \\
\hline
\end{tabular}

Source: Authors' calculations

A slight majority of respondents (53\%) agreed or totally agreed that a more appropriate wording of section $80 \mathrm{M}(1)$ would be where the words 'assumed to be derived' are replaced by 'may be derived'. $35 \%$ of respondents did not consider this proposal to be appropriate in removing any uncertainty.

Question 8: If a person, for example an outside party appointed by a bank to act as a facility agent, played no part in setting up the transaction and is merely there to ensure that the interests of the parties are adequately catered for, there is no reason to include them in the definition of promoter, and as such, the word 'managing' should be deleted from the section $80 \mathrm{~T}$ definition of 'promoter'. Do you agree with this statement? 
TABLE 11 Results of Question 8

\begin{tabular}{lccc}
\hline & Audit firms & Legalfirms & Total \\
& $(n=12)$ & $(n=5)$ & $(n=17)$ \\
& $\%$ & $\%$ & 6 \\
\hline Totally agree & 0 & 20 & 29 \\
\hline Agree & 25 & 40 & 30 \\
Neutral & 34 & 20 & 29 \\
Disagree & 33 & 20 & 0 \\
\hline Totally disagree & 0 & 0 & 6 \\
\hline Puestion not answered by respondent & 8 & 0 & 100 \\
\hline Total & 100 & 100 & $\%$ \\
\hline
\end{tabular}

Source: Authors' calculations

The results from the empirical study are inconclusive for this question: $35 \%$ of respondents agreed or totally agreed with the statement, 30\% remained neutral in this regard and $29 \%$ disagreed with the statement. As the results of the questionnaire neither corroborate nor contradict the submission made in the literature study, it would appear that SARS's (2010:26) recommendation of obtaining a letter from the disclosing promoter if any doubt exists as to whether a particular participant is the promoter, is perhaps the safest route to follow.

Question 9: Neither the Act nor SARS addresses the scenario where the promoter is also a lawyer, and as such, SARS should specifically take the client/attorney privilege into consideration for the disclosure obligation of section 800 . Do you agree with this statement?

TABLE 12 Results of Question 9

\begin{tabular}{lccc}
\hline & $\begin{array}{c}\text { Audit firms } \\
(n=12)\end{array}$ & $\begin{array}{c}\text { Legal firms } \\
(n=5)\end{array}$ & $\begin{array}{c}\text { Total } \\
(n=17)\end{array}$ \\
& $\%$ & $\%$ & $\%$ \\
\hline Totally agree & 8 & 60 & 24 \\
\hline Agree & 33 & 20 & 29 \\
Neutral & 0 & 0 & 0 \\
Disagree & 42 & 20 & 35 \\
Totally disagree & 8 & 0 & 6 \\
Question not answered by respondent & 9 & 0 & 6 \\
Total & 100 & 100 & 100 \\
\hline
\end{tabular}

Source: Authors' calculations 
A slight majority of respondents (53\%) agreed or totally agreed that SARS should specifically take the client/attorney privilege into consideration for the disclosure obligation of section 800 . However, $80 \%$ of legal firms agreed or totally agreed with the statement. This seems to suggest a greater appreciation of the implications of a possible infringement upon the client/attorney privilege among lawyers (compared with auditors). The results of the questionnaire therefore confirmed the conclusion drawn from the literature study, namely that as neither the Act nor SARS addresses the scenario where the promoter is also a lawyer, SARS should specifically take the client/attorney privilege into consideration for the disclosure obligation of section 800 .

\subsection{Summary of the survey}

This part of the article discussed the research design and the process followed in analysing the responses for the qualitative research performed. An interpretive approach was adopted, and a non-probability sampling method was considered appropriate. The tax partners of 30 audit firms and 10 legal firms were included in the sample. This section of the article described the data collection method and process, the design of the data collection instrument (the selfadministered questionnaire) and provided a statistical summary of the responses. In nearly all of the questions, the majority of respondents agreed with the conclusions drawn from the literature study.

\section{CONCLUSION}

An analysis of the RA provisions of the Act shows that the interpretation of these provisions is subjective and difficult to apply in practice. This is evidenced by the number of submissions that SAICA has made to SARS, the conflicting results to some of the survey questions and the lack of accurate, helpful guidance from SARS. Accordingly, determining when arrangements should be reported to SARS remains both problematic and onerous. Based on the literature study and the survey results, the following submissions and recommendations are made in this article:

- Amend the section 80T definition of 'arrangement' to align it with the section 80L General Anti-avoidance Rule (GAAR) definition so as to widen the scope of the RA provisions.

- The insertion of the word 'any' in the section $80 T$ definition of 'tax benefit' has the cumbersome effect of potentially including an indefinitely large number of ordinary, routine transactions.

- Although arrangements where the tax benefit does not exceed Rl million are excluded from the reportable arrangements provisions, some taxpayers could easily exceed this cut-off amount with just a few routine transactions.

- The section $80 \mathrm{~N}$ (1) list of 'plain-vanilla', excluded transactions should be extended to also include other routine operating transactions such as the acquisition of any asset, trading stock, consumables and services on credit.

- The onus of proof rests on the Commissioner of SARS to assume that a tax benefit has been or will be derived; the onus to disprove this assumption will accordingly rest on the taxpayer. 
- To cover scenarios where it is uncertain whether any tax benefit will flow, the words 'assumed to be derived' should be replaced by 'may be derived'.

- SARS should specifically address circumstances where not all the parties are given insight into the financial models contained in the arrangements.

- The section 80T definition of 'promoter' should be amended by deleting the word 'managing'; in doing so, a person who played no part in setting up the transaction, and who merely acted as a facilitator, would not be regarded as a 'promoter'.

- As regards the term 'promoter', SARS should specifically address circumstances where the promoter is not based in South Africa or where there is no promoter.

- SARS should specifically take the client/attorney legal privilege into consideration to adequately address the scenario where the promoter is also a lawyer.

- Legal professional privilege should also be extended to accountants who act as tax advisors.

- The two methods prescribed by SARS to determine the existence of a tax benefit (viz. the comparative method and the control transaction method) could also be used to determine whether or not a tax benefit was enhanced.

- The meaning of the requirement 'undue tax benefit' in section $80 \mathrm{~N}(4)$ is unclear, as neither the Act nor SARS provides clarity on how the 'undue' amount should be determined and by whom. The term 'undue tax benefit' should therefore be replaced with the term 'reporting requirement'.

Until such time as SARS adequately addresses the discrepancies in the Draft Guide and issues a properly revised guide, it is incumbent upon taxpayers to carefully consider whether their arrangements fall within the ambit of the RA provisions. A commercially sound transaction may unintentionally become reportable. 


\section{LIST OF REFERENCES}

Chambers Online Dictionary. (2010). [Online] Available: www.chambersharrap.co.uk (Accessed 17 June 2010).

Cilliers, C. (2008). Thou Shalt Not Peep at Thy Neighbour's Wife: Section 80A(c)(ii) of the Income Tax Act and the Abuse of Rights. South Africa: The Taxpayer, June 103-111.

Clegg, D. and Stretch, R. (2010). Income Tax in South Africa. Durban: LexisNexis.

Cliffe Dekker Hofmeyr. (2010). Tax matters, Winter 2010. [Online] Available:

http://www.cliffedekkerhofmeyr.com/export/sites/cdh/en/news/publications/2010/tax/downloads /Cliffe-Dekker-Hofmeyr-Tax-Matters-Winter-2010.pdf. (Accessed 14 January 2011).

Cooper, D.R. and Schindler, P.S. (2011). Business Research Methods, $11^{\text {th }}$ ed. New York: McGraw-Hill.

Croome, B. (2007). Legal Privilege in Tax Arena. South Africa: Accountancy SA, November 52-53.

De Koker, A.P. (2010). Silke on South African Income Tax. Durban: LexisNexis.

De Ville, J.R. (2000). Constitutional and Statutory Interpretation. Cape Town: Interdoc Consultants.

Du Plessis, L. (2002). Re-interpretation of Statutes. Durban: Butterworths.

Edward Nathan Sonnenbergs. (2011). United Kingdom Court of Appeal Rules on Legal Professional Privilege. SAICA: Integritax Newsletter, February 11-14.

Goldswain, G.K. (2008). The Purposive Approach to the Interpretation of Fiscal Legislation - the Winds of Change. Meditari Accountancy Research, 16(2) 107-121.

Her Majesty's Revenue and Customs (HMRC). (2011). Who Discloses? [Online] Available: http://www.hmrc.gov.uk/avoidance/who-discloses.pdf. (Accessed April 2011).

Johannesburg Stock Exchange (JSE). (201la). JSE Limited Listing Requirements, $2^{\text {nd }}$ edition. Durban: LexisNexis.

Johannesburg Stock Exchange (JSE). (2011b). The JSE list of Accredited Auditors. [Online] Available: http://www.jse.co.za. (Accessed 8 May 2011).

Meyerowitz, D., Emslie, T.S. and Davis, D.M. (2007). Tax Avoidance: Section 80A(c)(ii). South Africa: The Taxpayer, August 147-160.

Organisation for Economic Cooperation and Development (OECD). (2011). The Global Forum on Transparency and Exchange of Information for Tax Purposes. [Online] Available: http://www.oecd.org/dataoecd/32/45/43757434.pdf. (Accessed 1 May 2011).

Oxford Dictionaries Online. (2010). [Online] Available: www.oxforddictionaries.com. (Accessed 17 June 2010).

Perry, L. (2008). Legal Professional Privilege: Do You Really Know What This Covers? [Online] Available: http://www.bowman.co.za/LawArticles/Law-Article id 2132417337.asp. (Accessed 3 August 2011).

South African Institute of Chartered Accountants (SAICA). (2004). Call for Comment: Draft Reportable Arrangement Brochure. [Online] Available:

https://www.saica.co.za/Technicallnformation/Taxation/ContactwithStakeholders/SubmissionstoS ARS/Archives/tabid/1121/language/en-ZA/Default.aspx. (Accessed 19 June 2009). 
South African Institute of Chartered Accountants (SAICA). (2007a). Section 80 M of the Income Tax Act No. 58 of 1962: Examples of Transactions to be Included in an 'Excluded List of Transactions'. [Online] Available:

https://www.saica.co.za/Technicallnformation/Taxation/ContactwithStakeholders/SubmissionstoS ARS/Archives/tabid/1121/language/en-ZA/Default.aspx. (Accessed 18 June 2009).

South African Institute of Chartered Accountants (SAICA). (2007b). Call for Comment: Reportable Arrangements - Details of Routine Transactions. [Online] Available:

https://www.saica.co.za/Technicallnformation/Taxation/ContactwithStakeholders/SubmissionstoS ARS/Archives/tabid/1121/language/en-ZA/Default.aspx. (Accessed 18 June 2009).

South African Institute of Chartered Accountants (SAICA). (2008). Comments on the Definition of 'Promoter' as Contained in Section 80T of the Income Tax Act, No 58 of 1962 and Other Issues.

[Online] Available:

https://www.saica.co.za/Technicallnformation/Taxation/ContactwithStakeholders/SubmissionstoS ARS/Archives/tabid/1121/language/en-ZA/Default.aspx. (Accessed 18 June 2009).

South African Institute of Chartered Accountants (SAICA). (2010a). Call for Comment: Draft Guide to Reportable Arrangements. [Online] Available:

https://www.saica.co.za/Technicallnformation/Taxation/ContactwithStakeholders/SubmissionstoS ARS/Archives/tabid/1121/language/en-ZA/Default.aspx. (Accessed 27 May 2010).

South African Institute of Chartered Accountants (SAICA). (2010b). Examinable Taxation Pronouncements Qualifying Examination Part / January 2011. [Online] Available:

https://www.saica.co.za/LearnersStudents/Examinations/Informationonwhatwillbeexamined/Exami nablePronouncements/tabid/488/language/en-ZA/Default.aspx. (Accessed 8 May 2011).

South African Institute of Chartered Accountants (SAICA). (2011). Examinable Taxation Pronouncements Qualifying Examination Part IJanuary 2012. [Online] Available:

https://www.saica.co.za/LearnersStudents/Examinations/Informationonwhatwillbeexamined/Exami nablePronouncements/tabid/488/language/en-ZA/Default.aspx. (Accessed 8 May 2011).

South African Revenue Service (SARS). (2005). Reportable Arrangements Guide. [Online] Available: http://www.sars.gov.za/AllDocs/OpsDocs/Guides/LAPD-IT-G15\%20-

\%20Reportable\%20Arrangement\%20Guide\%20-\%20External\%20Guide.pdf. (Accessed 16 June 2009).

South African Revenue Service (SARS). (2006). Responses to Written Representations by Organisations to the Portfolio Committee on Finance on the Draft Revenue Laws Amendment Bill, 2006. [Online] Available: http://www.sars.gov.za/Legal/Preparation-of-

Legislation/Pages/Response-Documents.aspx. (Accessed 25 June 2010).

South African Revenue Service (SARS). (2008). Media Release: New Reportable Arrangements Legislation Takes Effect. [Online] Available:

http://www.sars.gov.za/AllDocs/Documents/MediaReleases/2008/SARS-MR-2008-012\%20-

$\% 20$ Media\%20Release $\% 20$ on\%20New\%20reportable\%20arrangements\%20legislation\%20takes\%20ef fect\%20-\%209\%20April\%202008.pdf. (Accessed 19 June 2009).

South African Revenue Service (SARS). (2010). Draft Guide to Reportable Arrangements. [Online] Available: http://www.sars.gov.za/Legal/Legal-Publications/Pages/Find-a-Guide.aspx. (Accessed 7 October 2013).

South African Revenue Service (SARS). (2013). Short Guide to the Tax Administration Act. [Online] Available: http://www.sars.gov.za/Legal/Legal-Publications/Pages/Find-a-Guide.aspx. (Accessed 6 June 2013). 
Stiglingh, M. (2008). Developing a Model to Evaluate the Quality of the Services Rendered by the South African Revenue Service. PhD thesis. University of Pretoria: Pretoria.

Venter, E.R. and Stiglingh, M. (2006a). The Timing of the Recognition of a Liability for Secondary Tax on Companies in Accordance with International Financial Reporting Standards. South African Journal of Accounting Research, 20(1) 83-118.

Venter, E.R. and Stiglingh, M. (2006b). Recognising an STC Liability Versus Recognising a Deferred Tax Asset for Unused STC Credits According to the IASB framework: a Comparison. Meditari Accountancy Research, 14(1) 103-120.

Wikipedia. (2011). Big Five Law Firms. [Online] Available: http://en.wikipedia.org/wiki/Big_Five_law_firms. (Accessed 17 May 2011).

World Accounting Intelligence. (2011). Top Global Networks / Associations by Income: 2009. [Online] Available: http://firm-rankings.vrl-financial-news.com. (Accessed 7 May 2011).

South African Legislation and Court Cases

South Africa. (2008). Government Gazette, No. 30941, Volume 514, 1 April 2008. Pretoria: Government Printer.

South Africa. (2009). The Constitution of the Republic of South Africa, Act 108 of 1996.

Pretoria: Government Printer.

South Africa. (2010). The Taxation Laws Amendment Act, Act 7 of 2010. Pretoria: Government Printer.

South Africa. (2011). The Taxation Laws Amendment Act, Act 24 of 2011. Pretoria: Government Printer.

South Africa. (2013). The Income Tax Act, Act 58 of 1962. Pretoria: Government Printer.

South Africa. (1993). The Interpretation Act, Act 33 of 1957. Pretoria: Government Printer.

South Africa. (2013). The Tax Administration Act, Act 28 of 2011. Pretoria: Government Printer.

CIR v. Conhage (Pty) Ltd (formerly Tycon (Pty) Ltd) (1999) 61 SATC 391

CIR v. Louw 1983 (3) SA 551 (A)

CIR v. Ocean Manufacturing Ltd 1990 (3) SA 610 (A)

Hayne and Co v. Kaffrarian Steam Mill Co Ltd 1919 AD 363

ITC 983 (25 SATC 55)

ITC 1307 (42 SATC 147)

ITC 1636 (60 SATC 267)

Meyerowitz v. CIR (1963) 25 SATC 287

Ovenstone v. CIR (1980) 42 SATC 55

SIR v. Consolidated Citrus Estates Ltd (1967) 38 SATC 126

SIR v. Gallagher (1978) 40 SATC 39

SIR v. Geusteyn, Forsyth and Joubert (1971) 33 SATC 113 
United Kingdom Legislation and Court Cases

United Kingdom. The Finance Act, 2004 (c.12). [Online] Available:

http://www.legislation.gov.uk/ukpga. (Accessed 21 June 2010).

IRC v. Duke of Westminster 193651 TLR 467, 19 TC 490

R (Prudential plc \& Anor) v. Special Commissioner of Income Tax \& Anor 2013 UKSC 1.

Australian Court Cases

Cridland v. Federal Commissioner of Taxation 1977140 CLR 330

New Zealand Court Cases

BNZ Investments Ltd v. CIR 200019 NZTC 15

Newton v. COT 19582 All ER 759 (PC) 
APPENDIX 1 - The reportable arrangements provisions as contained in their current format in the Tax Administration Act No. 28 of 2011, as amended

34. Definitions. - In this Part and in section 212, unless the context indicates otherwise, the following terms, if in single quotation marks, have the following meanings-

'arrangement' means any transaction, operation, scheme, agreement or understanding (whether enforceable or not);

'financial benefit' means a reduction in the cost of finance, including interest, finance charges, costs, fees and discounts on a redemption amount;

'financial reporting standards' means, in the case of a company required to submit financial statements in terms of the Companies Act, 2008 (Act No. 71 of 2008), financial reporting standards prescribed by that Act, or, in any other case, the Generally Accepted Accounting Practice or appropriate financial reporting standards that provide a fair presentation of the financial results and position of the taxpayer;

'participant', in relation to an 'arrangement', means-

(a) a 'promoter'; or

(b) a company or trust which directly or indirectly derives or assumes that it derives a 'tax benefit' or 'financial benefit' by virtue of an 'arrangement';

'pre-tax profit', in relation to an 'arrangement', means the profit of a 'participant' resulting from that 'arrangement' before deducting normal tax, which profit must be determined in accordance with 'financial reporting standards' after taking into account all costs and expenditure incurred by the 'participant' in connection with the 'arrangement' and after deducting any foreign tax paid or payable by the 'participant' in connection with the 'arrangement';

'promoter', in relation to an 'arrangement', means a person who is principally responsible for organising, designing, selling, financing or managing the reportable 'arrangement';

'tax benefit' includes avoidance, postponement or reduction of a liability for tax.

35. Reportable arrangements.

(1) An 'arrangement' is a reportable arrangement if it is listed in terms of subsection (2) or if a 'tax benefit' 'is or will be derived or is assumed to be derived by any 'participant' 'by virtue of the 'arrangement' and the 'arrangement'-

(a) contains provisions in terms of which the calculation of 'interest' as defined in section 24J of the Income Tax Act, finance costs, fees or any other charges is wholly or partly dependent on the assumptions relating to the tax treatment of that 'arrangement' (otherwise than by reason of any change in the provisions of a tax Act);

(b) has any of the characteristics contemplated in section 80C (2) (b) of the Income Tax Act, or substantially similar characteristics;

(c) gives rise to an amount that is or will be disclosed by any 'participant' in any year of assessment or over the term of the 'arrangement' as-

(i) a deduction for purposes of the Income Tax Act but not as an expense for purposes of 'financial reporting standards'; or

(ii) revenue for purposes of 'financial reporting standards' but not as gross income for purposes of the Income Tax Act; 
(d) does not result in a reasonable expectation of a 'pre-tax profit' for any 'participant'; or

(e) results in a reasonable expectation of a 'pre-tax profit' for any 'participant' that is less than the value of that 'tax benefit' to that 'participant' if both are discounted to a present value at the end of the first year of assessment when that 'tax benefit' is or will be derived or is assumed to be derived, using consistent assumptions and a reasonable discount rate for that 'participant'.

(2) The Commissioner may list an 'arrangement' by public notice, if satisfied that the 'arrangement' may lead to an undue 'tax benefit'.

(3) This section does not apply to an excluded 'arrangement' referred to in section 36.

36. Excluded arrangements.

(1) An 'arrangement' is an excluded 'arrangement' if it is-

(a) a debt in terms of which-

(i) the borrower receives or will receive an amount of cash and agrees to repay at least the same amount of cash to the lender at a determinable future date; or

(ii) the borrower receives or will receive a fungible asset and agrees to return an asset of the same kind and of the same or equivalent quantity and quality to the lender at a determinable future date;

(b) a lease;

(c) a transaction undertaken through an exchange regulated in terms of the Securities Services Act, 2004 (Act No. 36 of 2004); or

(d) a transaction in participatory interests in a scheme regulated in terms of the Collective Investment Schemes Control Act, 2002 (Act No. 45 of 2002).

(2) Subsection (1) applies only to an 'arrangement' that-

(a) is undertaken on a stand-alone basis and is not directly or indirectly connected to any other 'arrangement' (whether entered into between the same or different parties); or

(b) would have qualified as having been undertaken on a stand-alone basis as required by paragraph $(a)$, were it not for a connected 'arrangement' that is entered into for the sole purpose of providing security and if no 'tax benefit' is obtained or enhanced by virtue of the security 'arrangement'.

(3) Subsection (1) does not apply to an 'arrangement' that is entered into-

(a) with the main purpose or one of its main purposes of obtaining or enhancing a 'tax benefit'; or

(b) in a specific manner or form that enhances or will enhance a 'tax benefit'.

(4) The Commissioner may determine an 'arrangement' to be an excluded 'arrangement' by public notice, if satisfied that the 'arrangement' is not likely to lead to an undue 'tax benefit'.

37. Disclosure obligation.

(1) The 'promoter' must disclose the information referred to in section 38 in respect of a reportable arrangement.

(2) If there is no 'promoter' in relation to the 'arrangement' or if the 'promoter' is not a resident, all other 'participants' must disclose the information. 
(3) A 'participant' need not disclose the information if the 'participant' obtains a written statement from-

(a) the 'promoter' that the 'promoter' has disclosed the 'arrangement'; or

(b) any other 'participant', if subsection (2) applies, that the other 'participant' has disclosed the 'arrangement'.

(4) The 'arrangement' must be disclosed within 45 business days after an amount is first received by or has accrued to a 'participant' or is first paid or actually incurred by a 'participant' in terms of the 'arrangement'.

(5) SARS may grant extension for disclosure for a further 45 business days, if reasonable grounds exist for the extension.

38. Information to be submitted.

The 'promoter' or 'participant' must submit, in relation to a reportable arrangement, in the prescribed form and manner and by the date specified-

(a) a detailed description of all its steps and key features, including, in the case of an 'arrangement' that is a step or part of a larger 'arrangement', all the steps and key features of the larger 'arrangement';

(b) a detailed description of the assumed 'tax benefits' for all 'participants', including, but not limited to, tax deductions and deferred income;

(c) the names, registration numbers, and registered addresses of all 'participants';

(d) a list of all its agreements; and

(e) any financial model that embodies its projected tax treatment.

39. Reportable arrangement reference number.-SARS must, after receipt of the information contemplated in section 38 , issue a reportable arrangement reference number to each 'participant' for administrative purposes only.

212. Reportable arrangement penalty.

(1) A 'participant' who fails to disclose the information in respect of a reportable arrangement as required by section 37 is liable to a 'penalty', for each month that the failure continues (up to 12 months), in the amount of-

(a) R50 000, in the case of a 'participant' other than the 'promoter'; or

(b) R100 000, in the case of the 'promoter'.

(2) The amount of 'penalty' determined under subsection (1) is doubled if the amount of anticipated 'tax benefit' for the 'participant' by reason of the arrangement (within the meaning of section 35) exceeds R5 000000 , and is tripled if the benefit exceeds R10 000000. 
APPENDIX 2: $\quad$ The sample of audit and legal firms

The sample of audit firms (alphabetical order)

\begin{tabular}{|c|c|}
\hline Number & Organisation name \\
\hline 1 & ACT Audit Solutions Inc. \\
\hline 2 & AM Smith \& Co \\
\hline 3 & Baker Tilly Morrison Murray \\
\hline 4 & BDO Spencer \\
\hline 5 & Certified Master Auditors (South Africa) Inc. \\
\hline 6 & Charles Orbach \\
\hline 7 & Deloitte \& Touche Inc. \\
\hline 8 & Ernst \& Young Inc. \\
\hline 9 & Grant Thornton \\
\hline 10 & Greenwoods Chartered Accountants \\
\hline 11 & Horwath Leveton Boner \\
\hline 12 & IAPA \\
\hline 13 & KPMG \\
\hline 14 & LDP Inc. \\
\hline 15 & Logista International Inc. \\
\hline 16 & Mahdi Meyer \\
\hline 17 & Mazars \\
\hline 18 & Middel \& Partners \\
\hline 19 & Moore Stephens \\
\hline 20 & Nexia Southern Africa \\
\hline 21 & Ngubane Zeelie Incorporated \\
\hline 22 & Nkonki Inc. \\
\hline 23 & Nolands \\
\hline 24 & PKF South Africa \\
\hline 25 & PricewaterhouseCoopers \\
\hline 26 & RSM Betty \& Dickson \\
\hline 27 & SAB\&T Chartered Accountants \\
\hline 28 & SizweNtsaluba VSP \\
\hline 29 & TAG Incorporated \\
\hline 30 & Tuffias Sandberg KSI \\
\hline
\end{tabular}




\begin{tabular}{cl}
\hline $\begin{array}{c}\text { The sample of legal firms (alphabetical order) } \\
\text { Number }\end{array}$ & Organisation name \\
\hline 1 & Adams \& Adams \\
2 & Bell Dewar \\
3 & Bowman Gilfillan \\
4 & Cliffe Dekker Hofmeyr \\
\hline 5 & Edward Nathan Sonnenbergs \\
6 & Eversheds \\
7 & Norton Rose South Africa \\
8 & Shepstone \& Wylie \\
9 & Webber Wentzel \\
10 & Werksmans \\
\hline
\end{tabular}

